\title{
Characterization of Pythium Species Collected from a Multiple Time-Point Sampling of Cucurbits in South Carolina
}

\author{
Sean M. Toporek ${ }^{\dagger}$ and Anthony P. Keinath \\ Department of Plant and Environmental Sciences, Clemson University, Coastal Research and Education Center, Charleston, SC \\ 29414
}

\begin{abstract}
Species of Pythium cause root and stem rot in cucurbits, but no formal surveys have been conducted in the United States to identify which species are responsible. The cucurbit hosts bottle gourd, cucumber, Hubbard squash, and watermelon were transplanted in May, July, September, and November into sentinel plots in four and five different fields in 2017 and 2018, respectively, in South Carolina. Eight of the nine fields were replanted in March 2019. Isolates (600) were collected and identified by sequencing DNA of the mitochondrial cytochrome oxidase I region. The four most common species were $P$. spinosum ( $45.6 \%$ of all isolates),

isolated in May, July, and September, whereas P. spinosum and P. irregulare were predominantly isolated in November and March. Isolates of $P$. ultimum, $P$. irregulare, and $P$. spinosum were more virulent than isolates of $P$. myriotylum and $P$. aphanidermatum at $25^{\circ} \mathrm{C}$. Representative isolates were screened in vitro for sensitivity to three fungicides: mefenoxam, propamocarb, and oxathiapiprolin. All isolates were sensitive to mefenoxam and propamocarb, but these same isolates were insensitive to oxathiapiprolin, except those classified taxonomically in Pythium clade I.
\end{abstract} P. myriotylum (20.0\%), P. irregulare (15.3\%), and P. aphanidermatum (12.8\%). P. myriotylum and P. aphanidermatum were predominantly

Keywords: Pythium, cucurbits, survey, COX1, oxathiapiprolin

The family Cucurbitaceae is composed of 960 species within 115 genera. This diverse plant family ranks among the highest for numbers of species grown for human consumption (Robinson and Decker-Walters 1997). In the United States 2017 Census of Agriculture, 52,524 ha of watermelon (Citrullus lanatus [Thunb.] Matsum. \& Nakai), 48,423 ha of cucumber (Cucumis sativus L.), 37,863 ha of pumpkin (Cucurbita pepo L.), 28,909 ha of cantaloupe (Cucumis melo L.), and 28,405 ha of squash (Cucurbita maxima Duchesne) were harvested for a total of 167,720 ha of cucurbits, making it the third largest group of vegetables in the United States after potatoes and sweet corn (USDA-NASS 2018).

Several species within the soilborne plant pathogen genus Pythium are known to infect cucurbits and cause root and stem rots (Deadman 2017). Aboveground symptoms of cucurbits infected by Pythium spp. include stunting, wilting, chlorosis, damping-off, and girdling and darkening of the lower stem at the soil line. Standing water and low temperatures increase incidences of Pythium diseases in cucurbit seedlings. Mature plants are also susceptible, although symptoms are less severe than on younger plants, and root systems may develop brown necrotic lesions throughout the season (Deadman 2017).

Species of Pythium survive in the soil as thick-walled oospores that can persist for decades (Webster and Weber 2007). As a precursor to infection, Pythium spp. produce motile, swimming zoospores that navigate through water films and are chemotactically attracted to plant root exudates and, especially, exudates from germinating seeds

${ }^{\dagger}$ Corresponding author: S. M. Toporek; stopore@clemson.edu

Technical Contribution No. 6858 of the Clemson University Experiment Station.

Funding: This material is based upon work that is supported by the National Institute of Food and Agriculture, U.S. Department of Agriculture, under award number 2016-51181-25404 and project number SC-1700536.

The author(s) declare no conflict of interest.

Accepted for publication 20 May 2020.

(C) 2020 The American Phytopathological Society
(Martin and Loper 1999). Cultural management of Pythium diseases in cucurbits can be achieved by transplanting seedlings at a later growth stage, grafting to resistant cucurbit rootstocks, and planting in raised beds to reduce periods of soil saturation from heavy rainfall (Deadman 2017; Toporek and Keinath 2019). Soil fumigation with methyl bromide was once a general use control for soilborne pathogens of cucurbits, but that is no longer an available management strategy (Davis et al. 2008). The fungicides mefenoxam (FRAC code 4) and propamocarb (FRAC code 28) currently are labeled for use on cucurbits to preventatively manage Pythium diseases. The use of mefenoxam increased from 6 to $18 \%$ of the watermelon acreage in the United States between 2006 and 2014 (USDA-NASS 2019). Oxathiapiprolin (FRAC code 49) is a newly registered fungicide in the class piperidinyl thiazole isoxazolines, specifically targeting an oxysterol-binding protein (Pasteris et al. 2015). Oxathiapiprolin is an effective fungicide that controls many oomycete pathogens (e.g., Phytophthora nicotianae and Pseudoperonospora cubensis), but it is not labeled for control of Pythium spp. (Bittner and Mila 2016; Cohen 2015). Isolates of Pythium spp. are variably sensitive to these three fungicides (Miao et al. 2016). Isolates of several species of Pythium have developed resistance to propamocarb and mefenoxam, and some isolates in greenhouses are resistant to both fungicides (Moorman and Kim 2004).

Twenty-four species of Pythium have been reported to cause disease on species in the family Cucurbitaceae in countries around the world, although most reports have been for cucumber (Farr and Rossman 2020). The four most commonly reported species of Pythium infecting cucurbits are $P$. aphanidermatum (Edson) Fitzp. $(n=65$ individual reports), P. ultimum Trow, $(n=26), P$. debaryanum $(n=23)$, and $P$. irregulare Buisman $(n=9)$. $P$. debaryanum was not validly described in the past literature and could be a number of different species, including $P$. intermedium, $P$. ultimum, and probably $P$. sylvaticum W.A. Campb. \& F.F. Hendrix (Van der Plaats-Niterink 1981). Formal surveys have not been conducted in the United States to identify the species of Pythium that are predominantly responsible for causing diseases on species of cucurbits. Two surveys of greenhouse cucumber in Oman identified $P$. aphanidermatum as the most prevalent species followed by $P$. spinosum Sawada (Al-Sadi et al. 2007, 2012). Likewise, the most common species recovered in cantaloupe fields sampled in Iran were $P$. aphanidermatum (71.8\%), P. ultimum (22.3\%), and P. deliense (5.9\%). P. aphanidermatum and P. ultimum 
also have been recovered from various cucurbits in Iran, particularly $P$. aphanidermatum (Teymoori et al. 2012). Studies aimed at examining how season affects the species isolated from cucurbits are lacking; in most studies, isolates were collected at a single point in time. Recently, however, Philosoph et al. (2019) demonstrated a transition on cucumber between $P$. spinosum in cold winter months to $P$. aphanidermatum in warm summer months with mixed populations of the two species in intermediary months.

Communities of Pythium spp. in the soil are influenced by many factors associated with field management strategies. Incorporation of cover crops has been observed to stimulate Pythium spp. communities (Njoroge et al. 2008; Pankhurst et al. 1995). Soils treated with glyphosate showed an increase in Pythium taxa after application (Schlatter et al. 2018). Conversely, soils suppressive to Pythium spp. have been created using various sources of organic amendments in different agricultural systems (Dissanayake and Hoy 1999; Lumsden et al. 1987). Microbial taxa under organic compared with conventional management differ in diversity, especially under mineral compared with nonmineral fertilizer use; however, this relationship is rather complex (Hartmann et al. 2015). Martin and Loper (1999) argued Pythium spp. are good targets for biocontrol because of sensitivity to antagonistic microbial activity during saprophytic stages. Management strategies that increase microbial diversity would arguably have implications on Pythium spp. communities. Because of the cumulative effects various management strategies have on the soil microbiome and Pythium spp. communities, species activity and recovery may differ between organic and conventionally managed cucurbit fields.

Identification of individual species of Pythium was once a laborious task involving microscopic determination of morphological characters, but DNA barcodes have expedited this process (Van der Plaats-Niterink 1981). The mitochondrial cytochrome oxidase subunit 1 (COX1) and the nuclear internal transcribed spacer region of ribosomal DNA (ITS) are the sequencing targets recommended for identification of Pythium spp. (Robideau et al. 2011; Schroeder et al. 2013). Several recent surveys of Pythium spp. associated with different crops have utilized these barcode regions for reliable identification (Coffua et al. 2016; Del Castillo Múnera and Hausbeck 2016; Rojas et al. 2017a). Taxonomically, species within the genus Pythium have been broken up into 10 phylogenetic clades (A through J) based on ITS sequencing that correlate with differing sporangium morphology (LéVesque and De Cock 2004). Phytopythium, formerly Pythium clade K, has been described as a morphological intermediate between Pythium and the genus Phytophthora (de Cock et al. 2015).

The objectives of this research were to (i) identify Pythium spp. on symptomatic cucurbits planted in sentinel plots in organic and conventional fields sampled throughout the growing season, (ii) quantify virulence of Pythium spp. isolates on a susceptible watermelon cultivar, and (iii) screen Pythium spp. isolates for in vitro sensitivity to the fungicides mefenoxam, propamocarb, and oxathiapiprolin.

\section{Materials and Methods}

Sampling design. Sentinel plots planted with four different cucurbit genera and species grown from organic seeds were used to collect Pythium spp.: bottle gourd (Lagenaria siceraria [Peaceful Valley Farms, Grass Valley, CA]), cucumber (Cucumis sativus 'Marketmore 76' [Peaceful Valley Farms]), Hubbard squash (Cucurbita maxima 'Golden Hubbard' [Everwilde Farms, Sand Creek, WI]), and watermelon (Citrullus lanatus 'Sugar Baby' [Peaceful Valley Farms]). For plants to be transplanted at the first true leaf stage, watermelon and cucumber seeds were planted 18 days before transplanting, and bottle gourd and squash seeds were planted 14 days before transplanting. Seeds were sown into 96-cell trays containing a soilless, peat-based container mix (Fafard 3B or Metro-Mix 830; Sun Gro, Agawam, MA) if seedlings were to be planted into a conventional field and into an organic container mix (28.3 liters of Premium Organic Vegetable and Herb Mix [PROMIX, Quakertown, PA], 11.4 liters of peat, 3.8 liters of vermiculite, 3.8 liters of sand, and 0.5 liters of Nature Safe 10-2-8 All Season Fertilizer [Irving, $\mathrm{TX}]$ ) if seedlings were to be planted into an organic field. Seedlings were maintained in a greenhouse and watered daily until 2 days before transplanting, when they were placed in an outdoor hoop house to harden off and acclimate to ambient environmental conditions.

In each sentinel plot, plants were arranged in a randomized complete block design with 10 plants for each plant species in each of two blocks. Each sentinel plot was a single 48.7-m-long row with $0.6 \mathrm{~m}$ between plants. In 2017 and 2018, seedlings were transplanted on four dates during the year at 2-month intervals-May, July, September, and November - in four and five fields, respectively (Fig. 1). Plants then were monitored during a 5-week sampling period for symptoms of disease development, including stunting, wilting, chlorosis, damping-off, or girdling and darkening of the lower stem at the soil line, by visiting each field at least once per week. In 2019, eight of the nine fields were planted and sampled in March to include an earlier time in the growing season (Fig. 2). Symptoms of wilting, lower stem rot, yellowing, and stunting were considered potential indicators of infection by Pythium spp., and these plants were collected for isolation of the pathogen.

Culturing and storage of isolates. Isolation from symptomatic plants occurred within $24 \mathrm{~h}$ after collection. Roots and lower stems were rinsed under cold running tap water, surface disinfested for $30 \mathrm{~s}$ in $0.3 \%$ sodium hypochlorite, rinsed in sterile deionized water, and blotted dry with sterile paper towels. Four symptomatic root or lower stem pieces $(5 \mathrm{~mm}$ in length) from each plant were evenly spaced in 90-mm-diameter Petri plates containing water agar $(15 \mathrm{~g}$ of Bacto agar in 1 liter of deionized water) amended with rifampicin (10 mg/liter), ampicillin (250 mg/liter), and benomyl (10 mg/liter) (WA+RAB). Isolation plates were held at $23^{\circ} \mathrm{C}$ in the dark for 7 days and observed daily for colonies with mycelia that resembled Pythium spp. Single hyphae from potential colonies of Pythium spp. were transferred to fresh WA+RAB to avoid potential contamination. Single hyphae from these cultures were transferred to $20 \%$ V8 juice agar (V8A: $200 \mathrm{ml}$ of V8 juice, $15 \mathrm{~g}$ of Bacto agar, $3 \mathrm{~g}$ of $\mathrm{CaCO}_{3}$, and $800 \mathrm{ml}$ of deionized water) for short-term storage at $23^{\circ} \mathrm{C}$ to confirm purity. Isolates were then stored long-term in 2-ml plastic screw-cap tubes, and each tube contained three sterile hemp seeds (Nuts.com, Cranford, $\mathrm{NJ}$ ), $1 \mathrm{ml}$ of sterile deionized water, and two 5-mmdiameter V8A plugs from the edge of an actively growing colony. All isolates of Pythium spp. were stored in duplicate by placing tubes in cryo/freezer boxes, which were maintained at $23^{\circ} \mathrm{C}$ and away from direct light.

DNA extraction and PCR. For each isolate, one 5-mm-diameter plug from an actively growing V8A culture was placed in $50 \mathrm{ml}$ of sterile $20 \%$ V8 broth (per liter: $200 \mathrm{ml}$ of V8 juice, $3 \mathrm{~g}$ of $\mathrm{CaCO}_{3}$, and $800 \mathrm{ml}$ of deionized water) in a $250-\mathrm{ml}$ Erlenmeyer flask. Cultures were incubated for 7 days at $23^{\circ} \mathrm{C}$ in the dark; then, $50 \mathrm{mg}$ of mycelium was removed, and DNA was extracted using a Synergy 2.0 Plant DNA Extraction Kit (OPS Diagnostics, Lebanon, NJ), following the manufacturer's instructions.

For each isolate of Pythium spp., the COX1 region of the mitochondrial DNA was amplified using the primers Fm85mod and OomCoxI-Levup (Robideau et al. 2011). The PCR reaction volume of $25 \mu \mathrm{l}$ contained $1 \times$ GoTaq Green Master Mix (Promega, Madison, WI), $0.8 \mu \mathrm{M}$ of each forward and reverse primer, $6.5 \mu \mathrm{l}$ of nucleasefree water, and $2 \mu \mathrm{l}$ of template DNA. Amplifications were performed with a PTC-200 thermal cycler (Bio-Rad, Hercules, CA) as follows: $95^{\circ} \mathrm{C}$ for $2 \mathrm{~min} ; 35$ cycles at $95^{\circ} \mathrm{C}$ for $1 \mathrm{~min}, 55^{\circ} \mathrm{C}$ for $1 \mathrm{~min}$, and $72^{\circ} \mathrm{C}$ for $1 \mathrm{~min}$; and final extension at $72^{\circ} \mathrm{C}$ for $10 \mathrm{~min}$. PCR products were visualized on a $1.5 \%$ agarose gel to verify amplification.

Amplicons were sequenced by Sanger sequencing in both directions using Big Dye V3.1 chemistry and run on ABI 3730XL instruments (Functional Biosciences, Madison, WI). In a few instances, the alternative reverse primer OomCoxI-Levlo was used when the amplicon generated by OomCoxI-Levup did not sequence properly. Resulting DNA sequence.ab1 files were imported to and manipulated in Geneious R11 (Geneious, Auckland, NZ). Pairwise alignments of the forward and reverse sequences were made using Geneious Alignment. Consensus sequence ends were trimmed of any regions with more than a $5 \%$ chance of an error per base. Consensus sequences 
were queried in the nonredundant GenBank nucleotide database at the National Center for Biotechnology Information and compared only to verified COX1 sequences from isolates of Pythium spp. (Robideau et al. 2011). An isolate was identified as a specific species of Pythium based on $97 \%$ or greater similarity to the sequence of a verified isolate of that species. $P$. ultimum and $P$. irregulare are each part of a species complex, the members of which are indistinguishable using either ITS or COX1 barcoding regions, so isolates were identified only by the broader species name (sensu lato) (Robideau et al. 2011). Six isolates were $97 \%$ or more similar to verified isolates of both $P$. coloratum Vaartaja (HQ708550) and $P$. dissotocum Drechsler (HQ708575); therefore, these isolates were labeled

\begin{tabular}{|c|c|c|c|c|c|c|c|c|c|c|}
\hline & \multicolumn{4}{|c|}{2017} & \multicolumn{5}{|c|}{2018} & \\
\hline & $1 c$ & 20 & $3 c$ & 40 & $5 c$ & 60 & $7 \mathrm{c}$ & $8 c$ & 90 & \\
\hline May & 50.0 & 21.4 & 27.3 & 44.4 & 0.0 & 16.7 & & 0.0 & 16.7 & \\
\hline Jul & 100 & 11.7 & 84.8 & 0.0 & 66.7 & & & 33.3 & 5.4 & \\
\hline Sep & 5.6 & 0.0 & 0.0 & 100 & 0.0 & & & 36.4 & 0.0 & aphanidermatum \\
\hline Nov & 0.0 & 0.0 & 0.0 & 0.0 & 0.0 & & 0.0 & 0.0 & 0.0 & \\
\hline May & 50.0 & 71.4 & 18.2 & 55.6 & 0.0 & 83.3 & & 0.0 & 16.7 & \\
\hline Jul & 0.0 & 24.7 & 13.0 & 0.0 & 33.3 & & & 66.7 & 91.9 & \\
\hline Sep & 38.9 & 63.6 & 0.0 & 0.0 & 0.0 & & & 63.6 & 100 & r. myriocyium \\
\hline Nov & 0.0 & 0.0 & 0.0 & 0.0 & 0.0 & & 0.0 & 0.0 & 0.0 & \\
\hline May & 0.0 & 0.0 & 0.0 & 0.0 & 0.0 & 0.0 & & 0.0 & 33.3 & \\
\hline Jul & 0.0 & 0.0 & 0.0 & 0.0 & 0.0 & & & 0.0 & 0.0 & $P$ irreaulare \\
\hline Sep & 16.7 & 4.5 & 0.0 & 0.0 & 0.0 & & & 0.0 & 0.0 & r. IIreguiare \\
\hline Nov & 12.0 & 6.4 & 4.9 & 82.0 & 0.0 & & 82.6 & 12.0 & 11.9 & \\
\hline May & 0.0 & 0.0 & 18.2 & 0.0 & 0.0 & 0.0 & & 0.0 & 33.3 & \\
\hline Jul & 0.0 & 0.0 & 0.0 & 0.0 & 0.0 & & & 0.0 & 0.0 & \\
\hline Sep & 27.8 & 22.7 & 100 & 0.0 & 0.0 & & & 0.0 & 0.0 & P. spinosum \\
\hline Nov & 86.0 & 87.2 & 85.4 & 18.0 & 100 & & 13.0 & 80.0 & 88.1 & \\
\hline May & 0.0 & 0.0 & 36.4 & 0.0 & 0.0 & 0.0 & & 0.0 & 0.0 & \\
\hline Jul & 0.0 & 0.0 & 2.2 & 0.0 & 0.0 & & & 0.0 & 0.0 & P ultimum \\
\hline Sep & 0.0 & 0.0 & 0.0 & 0.0 & 0.0 & & & 0.0 & 0.0 & r. cintmima \\
\hline Nov & 0.0 & 0.0 & 7.3 & 0.0 & 0.0 & & 0.0 & 0.0 & 0.0 & \\
\hline May & 0.0 & 0.0 & 0.0 & 0.0 & 0.0 & 0.0 & & 0.0 & 0.0 & \\
\hline Jul & 0.0 & 3.9 & 0.0 & 0.0 & 0.0 & & & 0.0 & 0.0 & \\
\hline Sep & 11.1 & 9.1 & 0.0 & 0.0 & 0.0 & & & 0.0 & 2.7 & Phy. helicoides \\
\hline Nov & 0.0 & 0.0 & 0.0 & 0.0 & 0.0 & & 0.0 & 0.0 & 0.0 & \\
\hline May & 0.0 & 0.0 & 0.0 & 0.0 & 0.0 & 0.0 & & 0.0 & 0.0 & \\
\hline Jul & 0.0 & 0.0 & 0.0 & 0.0 & 0.0 & & & 0.0 & 0.0 & P. coloratum/ \\
\hline Sep & 0.0 & 0.0 & 0.0 & 0.0 & 0.0 & & & 0.0 & 0.0 & dissotocum \\
\hline Nov & 2.0 & 2.1 & 0.0 & 0.0 & 0.0 & & 4.3 & 4.0 & 4.8 & \\
\hline May & 0.0 & 0.0 & 0.0 & 0.0 & 0.0 & 0.0 & & 0.0 & 0.0 & \\
\hline Jul & 0.0 & 0.0 & 0.0 & 0.0 & 0.0 & & & 0.0 & 0.0 & P. sylvaticum \\
\hline Sep & 0.0 & 0.0 & 0.0 & 0.0 & 0.0 & & & 0.0 & 0.0 & \\
\hline Nov & 0.0 & 4.3 & 2.4 & 0.0 & 0.0 & & 0.0 & 4.0 & 0.0 & \\
\hline May & 0.0 & 7.1 & 0.0 & 0.0 & 100 & 0.0 & & 0.0 & 0.0 & \\
\hline Jul & 0.0 & 0.0 & 0.0 & 0.0 & 0.0 & & & 0.0 & 0.0 & \\
\hline Sep & 0.0 & 0.0 & 0.0 & 0.0 & 0.0 & & & 0.0 & 0.0 & , reaminicum \\
\hline Nov & 0.0 & 0.0 & 0.0 & 0.0 & 0.0 & & 0.0 & 0.0 & 0.0 & \\
\hline
\end{tabular}

Fig. 1. Frequency of recovery of eight species of Pythium (P.) and one species of Phytopythium (Phy.) from nine cucurbit fields in South Carolina during four sampling periods in 2017 and 2018. Columns are headed by the numbers 1 to 9 , indicating different fields, with $0=$ organically managed field and $c=$ conventionally managed field. Data shown are the percentage of isolates of each species out of the total number of isolates recovered for each field at that sampling date. Darker shades of red indicate a higher frequency of recovery of a particular Pythium species than lighter shades of red. Blue indicates no recovery of any isolates of that particular Pythium species. Black indicates that the field was not sampled in the given month. 
P. coloratum/dissotocum. Representative sequences for isolates in this survey were deposited in GenBank under accession numbers MT002462 and MT222337 to MT222935.

Fungicide sensitivity testing. Representative isolates of Pythium spp. from the survey were assayed for sensitivity to three oomycetespecific fungicides in their commercial formulations: mefenoxam (Ridomil Gold 4 SL, Syngenta Crop Protection, Greensboro, NC), propamocarb (Previcur Flex 6 SL, Bayer Crop Science, Research Triangle Park, NC), and oxathiapiprolin (Orondis A [A20941A], Syngenta Crop Protection). For each species of Pythium identified in each sample period, a maximum of three isolates were selected for screening. If possible, no two isolates of any Pythium species from a given sample period were selected from the same field or cucurbit species.

The fungicides were incorporated into agar media at four or five concentrations to test isolates for sensitivity. Mefenoxam $(0.01$, $0.03,0.1,0.3$, and $1.0 \mathrm{mg}$ of active ingredient [a.i.]/liter) and oxathiapiprolin $(0.01,0.1,1.0,10.0$, and $100.0 \mathrm{mg}$ of a.i./liter) were added to corn meal agar (CMA; per liter: $17 \mathrm{~g}$ of corn meal agar and 1,000 ml of deionized water). Propamocarb (0.1, 1.0, 10.0, and $100.0 \mathrm{mg}$ of a.i./liter) was added to 5\% clarified V8A (per liter: $50 \mathrm{ml}$ of V8 juice, $15 \mathrm{~g}$ of Bacto agar, and $3 \mathrm{~g}$ of $\mathrm{CaCO}_{3}$ ) due to an observed irregular growth pattern expressed by some isolates grown on CMA amended with propamocarb. Nonamended CMA and 5\% clarified V8A were prepared for controls.

The experiment was a completely randomized design, conducted twice, with two replicate plates per isolate at each concentration for each fungicide and nonamended controls (Keinath 2015). CMA plugs (5-mm diameter) from 3-day-old cultures were inverted in the center of $90-\mathrm{mm}$-diameter Petri dishes, each containing $25 \mathrm{ml}$ of either fungicide-amended or non-fungicide-amended medium. Cultures were incubated in the dark at $23^{\circ} \mathrm{C}$ for $36 \mathrm{~h}$. Two perpendicular radial measurements were taken with a digital caliper from each colony at the end of the 36-h incubation period. All colony radii on fungicide-amended media of each isolate were represented as relative growth compared with growth on the nonamended CMA or 5\% V8A control plates.

Virulence assay. Sixteen isolates, representing seven species of Pythium, were used to inoculate seedlings of the susceptible watermelon cultivar 'Estrella' (Seedway, Hall, NY) in a growth chamber (Table 1). To avoid a potential effect of host specificity, all isolates selected for screening were recovered from symptomatic watermelon seedlings during the survey. Seven Estrella seeds were sewn $2.5-\mathrm{cm}$ deep and evenly spaced within 15.2-cm-diameter pots filled with Metro-Mix 830 . Seedlings were germinated and grown at $30^{\circ} \mathrm{C}$,
$45 \%$ relative humidity, and a $12-\mathrm{h}$ photoperiod in a growth chamber for 7 days before inoculation. On day 7 , the growth chamber temperature was lowered to $25^{\circ} \mathrm{C}$, and all seedings except the five most uniform ones were removed.

For inoculation, isolates of Pythium spp. were grown at $23^{\circ} \mathrm{C}$ in the dark on $20 \%$ V8A. Plugs (6-mm diameter) from 3-day-old cultures were placed against the seedling stem just below the container mix surface. Plugs from noncolonized $20 \%$ V8A plates were placed against seedlings in control pots. The experimental design was a randomized complete block with five replicate pots for each isolate (one per block), and each pot contained five seedlings. The experiment was conducted twice. Disease incidence data were recorded daily for 7 days as the number of plants damped-off per pot. One diseased seedling was used for isolation of each isolate of Pythium spp., and the COX1 region was sequenced as described previously to confirm pathogen identity. Area under the disease progress curve (AUDPC) was calculated from disease incidence data from both experiments (Shaner and Finney 1977).

Statistical analyses. Data on recovery of the total numbers of isolates of Pythium species, $P$. spinosum, $P$. irregulare, $P$. myriotylum Drechsler, and $P$. aphanidermatum from surveyed plants were analyzed using SAS PROC CATMOD (SAS version 9.3; SAS, Cary, $\mathrm{NC)}$ for categorical data, which uses a $\chi^{2}$ statistic to determine treatment effects. The proportion of plants from which isolates of Pythium spp. were or were not recovered (a binary response) was transformed by calculating the logit, and the linear model parameters then were estimated using the maximum likelihood option. To get models that included zero values for some categories to converge (i.e., arrive at a unique solution), observed proportions were replaced with a Bayes estimator calculated as follows:

$$
x=(c t+k / r) \times n /(n+k)
$$

where $x$ is the transformed proportion, $c t$ is the count of plants with (or without) Pythium spp., $r$ is 2 (for a binary response), $k$ is a constant (which was set equal to $r$ ), and $n$ is the total number of plants per treatment combination (Santner and Duffy 1989). Stepwise model reduction was done to improve the sensitivity of the analysis. When treatment effects were significant, contrast statements were written to compare treatment levels. Three-way interactions of field type, month, and host were examined in 2019, and four-way interactions of year, field type, month, and host were examined for combined 2017 and 2018 datasets. Significant two-way interactions were split by including nested-by-value effects for one of the factors in model statements. Proportions were generated using the predict option to back-transform logit values.

$\begin{array}{cccccccccl}\mathbf{1 c} & \mathbf{2 0} & \mathbf{3 c} & \mathbf{4 0} & \mathbf{5 c} & \mathbf{6 0} & \mathbf{7 c} & \mathbf{8 c} & \mathbf{9 0} & \\ 0.0 & 0.0 & 0.0 & 0.0 & 0.0 & & 0.0 & 0.0 & 0.0 & \text { P. aphanidermatum } \\ 0.0 & 0.0 & 0.0 & 0.0 & 0.0 & & 0.0 & 0.0 & 0.0 & \text { P. myriotylum } \\ 11.1 & 5.6 & 4.8 & 0.0 & 25.0 & & 0.0 & 30.0 & 0.0 & \text { P. irregulare } \\ 77.8 & 88.9 & 66.7 & 100.0 & 75.0 & & 0.0 & 70.0 & 100.0 & \text { P. spinosum } \\ 11.1 & 5.6 & 28.6 & 0.0 & 0.0 & & 100.0 & 0.0 & 0.0 & \text { P. ultimum } \\ 0.0 & 0.0 & 0.0 & 0.0 & 5.0 & & 0.0 & 0.0 & 0.0 & \text { Phy. helicoides } \\ 0.0 & 0.0 & 0.0 & 0.0 & 5.0 & & 0.0 & 0.0 & 0.0 & \text { P. coloratum / dissotocum } \\ 0.0 & 0.0 & 0.0 & 0.0 & 5.0 & & 0.0 & 0.0 & 0.0 & \text { P. sylvaticum } \\ 0.0 & 0.0 & 0.0 & 0.0 & 0.0 & & 0.0 & 0.0 & 0.0 & \text { P. acanthicum }\end{array}$

Fig. 2. Frequency of recovery of eight species of Pythium $(P$.$) and one species of Phytopythium (Phy.) from nine cucurbit fields in South Carolina in March 2019. Column headings:$ the numbers 1 to 9 identify individual fields, and letters identify field management type with $0=$ organic and $c=$ conventional. Data shown are the percentage of isolates of each species out of the total number of isolates recovered for each field at that sampling date. Darker shades of red indicate a higher frequency of recovery of a particular $P y t h i u m$ species than lighter shades of red. Blue indicates no recovery of any isolates of that particular Pythium species. Black indicates that the field was not sampled in the given month. 
Data from both fungicide experiments were combined. Effective concentration $\left(\mathrm{EC}_{50}\right)$ values were calculated for each isolate and fungicide combination by regressing relative colony radii against the base-10 logarithm of the concentrations of each fungicide using PROC GLM in SAS (Keinath 2015). Linear regression equations were solved to calculate $\mathrm{EC}_{50}$ values for each fungicide/isolate combination. $\mathrm{EC}_{50}$ values for isolates screened against different fungicide concentrations were analyzed using simple linear regression (JMP

Table 1. Virulence of 16 isolates of six species of Pythium and one species of Phytopythium inoculated onto seedlings of watermelon cultivar Estrella in a growth chamber

\begin{tabular}{|c|c|c|}
\hline Species & Isolate & AUDPC value ${ }^{x}$ \\
\hline P. ultimum & $\mathrm{J} 17-3$ & $16.1 \mathrm{a}^{\mathrm{y}}$ \\
\hline P. ultimum & M17-56 & $15.1 \mathrm{a}$ \\
\hline P. irregulare & N18-50 & $12.8 \mathrm{abc}$ \\
\hline P. spinosum & N18-2 & $12.6 \mathrm{abc}$ \\
\hline P. spinosum & N18-4 & $12.5 \mathrm{abc}$ \\
\hline P. myriotylum & M18-1 & $10.0 \mathrm{bcd}$ \\
\hline P. aphanidermatum & M18-5 & 8.9 bcde \\
\hline P. irregulare & N18-10 & $8.3 \mathrm{cdef}$ \\
\hline P. aphanidermatum & N18-5 & $6.9 \mathrm{def}$ \\
\hline P. spinosum & N18-13 & $5.9 \mathrm{def}$ \\
\hline P. myriotylum & $\mathrm{J} 18-32$ & $5.0 \mathrm{defg}$ \\
\hline P. myriotylum & M18-a8 & $4.6 \mathrm{efg}$ \\
\hline P. aphanidermatum & $\mathrm{J} 17-23$ & $4.6 \mathrm{efg}$ \\
\hline P. aphanidermatum & M17-42 & $3.6 \mathrm{fg}$ \\
\hline P. coloratum/P. dissotocum & N18-29 & $0.0 \mathrm{~g}$ \\
\hline Phytopythium helicoides & $\mathrm{J} 17-40$ & $0.0 \mathrm{~g}$ \\
\hline Preplanned comparison & & $P$ value \\
\hline Warm-season versus cool-season species ${ }^{\mathrm{z}}$ & $\ldots$ & 0.0002 \\
\hline
\end{tabular}

$\mathrm{x}$ AUDPC $=$ area under the disease progress curve calculated from disease incidence. Incidence was determined by counting the numbers of diseased seedlings each day for 7 days in a pot containing five inoculated seedlings. The experiment was done at $25^{\circ} \mathrm{C}, 12-\mathrm{h}$ photoperiod, and $45 \%$ relative humidity.

y Mean AUDPC values followed by the same letter are not significantly different based on Fisher's protected least significant difference $(P<0.05)$.

${ }^{z} P$. aphanidermatum and $P$. myriotylum are classified as warm-season species, and $P$. irregulare and $P$. spinosum are classified as cool-season species.
Pro version 14; SAS Institute). $\mathrm{EC}_{50}$ values were set as the response variable, and species was set as the model effect variable. Only species with two or more isolates were included in this analysis. Least square means were compared using Student's $t$ tests.

AUDPC values from the virulence experiment were combined and transformed to square root values to correct for nonnormality and analyzed with a mixed-model maximum likelihood analysis (SAS PROC MIXED), with Pythium spp. as a fixed effect and experiment and block as random effects. Residuals from analysis of variance were checked for nonnormality and inequality of variance with SAS PROC UNIVARIATE. Back-transformed least-squares means are shown, and treatment means were compared with Student $t$ tests. Preplanned, single-degree-of-freedom contrasts were used to compare species collected in relatively warm and cool months.

\section{Results}

Field sampling. A total of 600 isolates, including eight species of Pythium and one species of Phytopythium (Phy.), were recovered during all sampling periods. However, $93.8 \%$ of all isolates $(n=$ $563)$ belonged to four species: $P$. spinosum $(n=274), P$. myriotylum $(n=120), P$. irregulare $(n=92)$, and $P$. aphanidermatum $(n=77)$; each of these species was recovered at least once from eight of the nine fields sampled (Figs. 1 and 2). The other five species- $P$. ultimum $(n=17)$, Phy. helicoides (Drechsler) Abad, de Cock, Bala, Robideau, Lodhi \& Lévesque $(n=8), P$. coloratum/dissotocum $(n=6), P$. sylvaticum $(n=4)$, and $P$. acanthicum Drechsler $(n=2)$ were much less common and were recovered from one to five fields. A total of 238 isolates were recovered from watermelon seedlings, 149 isolates from cucumber seedlings, 145 isolates from Hubbard squash seedlings, and 68 isolates from bottle gourd seedlings (Fig. 3 ). Together, $P$. spinosum, $P$. myriotylum, $P$. irregulare, and $P$. aphanidermatum accounted for 93.7, 93.3, 93.8, and 95.6\% of all isolates recovered from watermelon, cucumber, Hubbard squash, and bottle gourd, respectively. $P$. acanthicum and Phy. helicoides were not recovered from bottle gourd or cucumber, $P$. sylvaticum was not recovered from watermelon, and $P$. ultimum was not recovered from bottle gourd. Sixteen new associations between different cucurbit hosts were found: nine for the world and seven for the United States (Table 2).

In 2017 and 2018, there was a significant interaction of year by month $(P=0.0012)$ and year by field type $(P=0.0491)$ on the total

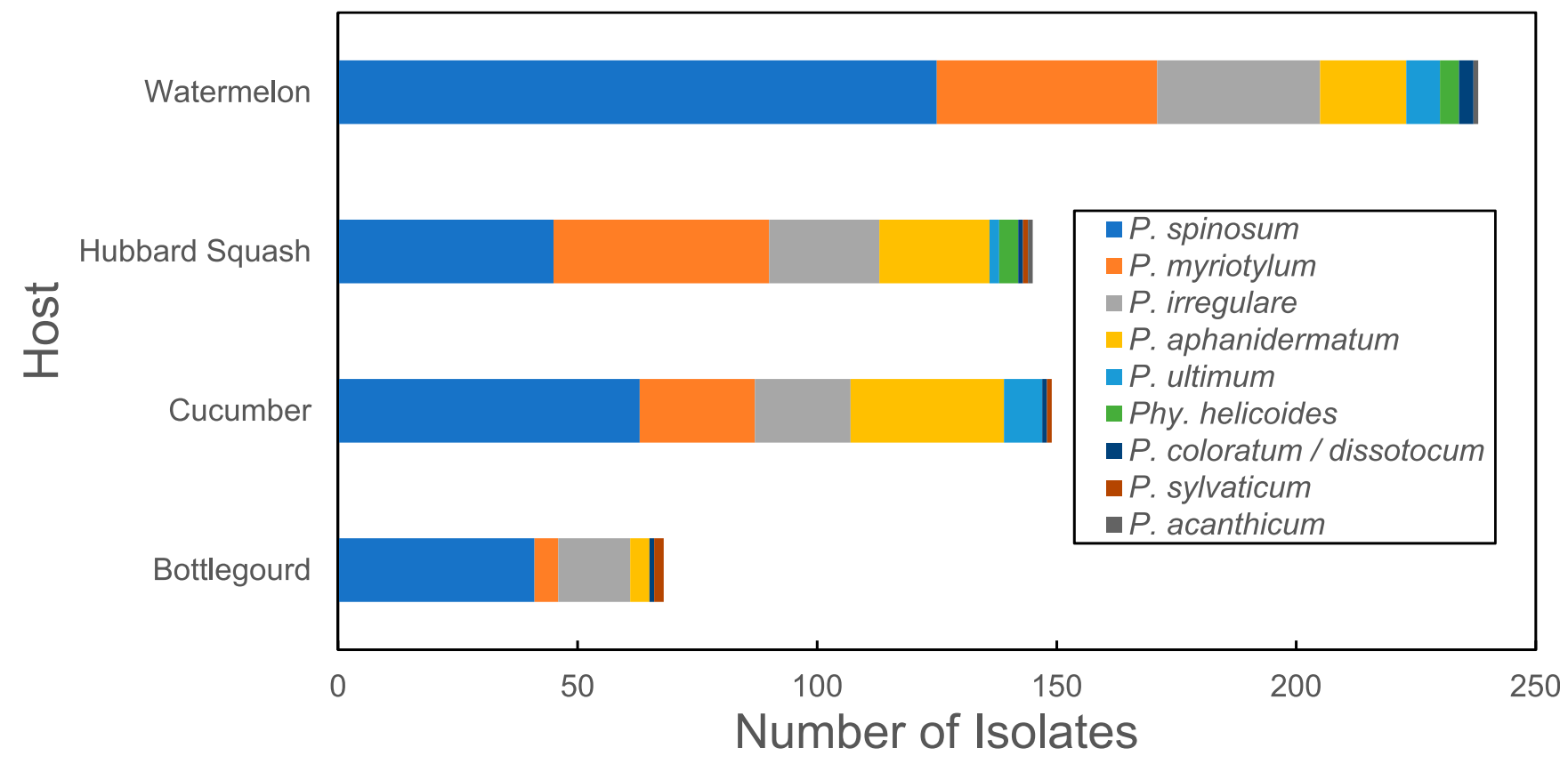

Fig. 3. Numbers of isolates of eight species of Pythium (P.) and one species of Phytopythium (Phy.) recovered from four different cucurbit hosts growing in nine fields in South Carolina during 2017, 2018, and 2019. 
recovery of isolates of Pythium spp. from symptomatic cucurbits (Table 3). Total recovery was higher in May 2017 (0.57) than May $2018(0.35)(P=0.0182)$ and in September $2017(0.82)$ than September $2018(0.34)(P<0.0001)$. Although there was no difference in the total recovery rates between field types within years, there was a higher total recovery in 2017 conventional fields $(0.75)$ compared with 2018 conventional fields $(0.51)(P<0.0001)$.

In 2017 and 2018, month significantly influenced total recovery and recovery of all four major species (Table 3$)$. Greater $P$. aphanidermatum recovery was observed in May $(0.36)(P<0.0001)$, July, (0.45) $(P=0.0023)$, and September $(0.23)(P=0.011)$ than in November $(0.08)$ (Table 4$)$. Greater $P$. myriotylum recovery also was observed in May $(0.51)(P<0.0001)$, July $(0.51)(P=0.0003)$, and September $(0.53)(P<0.0001)$ than in November $(0.08)$. Greater $P$. irregulare recovery was observed in November (0.31) compared with July $(0.09)(P=0.0011)$. Greater $P$. spinosum recovery was observed in November $(0.65)$ compared with May $(0.21)(P<0.0001)$, July $(0.09)(P<0.0001)$, and September $(0.27)(P=0.0045)$.

Table 2. New associations between cucurbit hosts and Pythium species recovered from diseased cucurbits in South Carolina ${ }^{z}$

\begin{tabular}{|c|c|c|}
\hline Host & Pythium species & New association \\
\hline \multirow{6}{*}{$\begin{array}{l}\text { Bottle gourd } \\
\text { (Lagenaria siceraria) }\end{array}$} & P. aphanidermatum & United States \\
\hline & P. dissotocum & World \\
\hline & P. irregulare & World \\
\hline & P. myriotylum & World \\
\hline & P. spinosum & World \\
\hline & P. sylvaticum & World \\
\hline \multirow{7}{*}{$\begin{array}{l}\text { Hubbard squash } \\
\text { (Cucurbita maxima) }\end{array}$} & P. acanthicum & World \\
\hline & P. irregulare & United States \\
\hline & P. myriotylum & World \\
\hline & P. spinosum & United States \\
\hline & P. splendens & World \\
\hline & P. sylvaticum & World \\
\hline & P. ultimum & World \\
\hline \multirow{3}{*}{$\begin{array}{l}\text { Cucumber } \\
\text { (Cucumis sativus) }\end{array}$} & P. irregulare & United States \\
\hline & P. spinosum & United States \\
\hline & P. sylvaticum & United States \\
\hline
\end{tabular}

${ }^{\mathrm{z}}$ Based on Farr and Rossman (2020).
Recovery of both $P$. myriotylum $(P=0.0298)$ and $P$. aphanidermatum $(P=0.0493)$ had a significant three-way interaction of year by month by field type (Table 3 ). However, the effect of month was substantially greater for both species (both $P<0.0001$ ), and the effects of year and field type by themselves were not significant $(P \geq 0.1415$ for field type and $P \geq 0.8001$ for year).

In 2017 and 2018, cucurbit host significantly influenced recovery of $P$. aphanidermatum $(P=0.04)$, with greater recovery from cucumber $(0.28)$ than watermelon $(0.16)$ (Table 3$)$. Recovery of both $P$. irregulare $(P=0.0144)$ and $P$. spinosum $(P=0.0205)$ had a significant month by field type interaction. Across all fields sampled in November for both years, there was greater recovery of $P$. irregulare $(0.46)$ in conventionally managed than in organically managed fields (0.16) $(P<0.0001)$ and greater recovery of $P$. spinosum in organically managed fields $(0.80)$ than in conventionally managed fields (0.51) $(P<0.0001)$, but the two field types did not differ in other months (Fig. 1).

In March 2019, there was a significant effect of field type ( $P=$ $0.0379)$ and host $(P=0.0427)$ on total recovery of all isolates of Pythium spp. from symptomatic cucurbits (Table 5). Recovery was greater from organically managed $(0.83)$ than conventionally managed fields $(0.66)$. Total recovery rates from watermelon $(0.81)$ were higher than those from cucumber $(0.65)(P=0.0494)$ and Hubbard squash $(0.33)(P=0.0183)$. No isolates were recovered from bottle gourd in March 2019 from any fields.

Virulence of Pythium species. Virulence of six species of Pythium and Phy. helicoides was based on disease progress over a 7-day period and AUDPC values for two trials combined. AUDPC values for the 16 isolates varied among species and ranged from 0 to 16.1 (Table 1). P. coloratum/dissotocum isolate N18-29 and Phy. helicoides isolate J17-40 did not cause disease in either trial. The two isolates of $P$. ultimum were more virulent than 11 other isolates, including all isolates of $P$. myriotylum and $P$. aphanidermatum, but not $P$. irregulare isolate $\mathrm{N} 18-50$ and $P$. spinosum isolates $\mathrm{N} 18-2$ and N18-4. The preplanned comparison of the warm-season species of $P$. aphanidermatum and $P$. myriotylum (mean AUDPC for seven isolates $=6.2$ ) to the cool-season species of $P$. spinosum and $P$. irregulare (mean AUDPC for five isolates $=10.4$ ) demonstrated that coolseason species were more virulent at $25^{\circ} \mathrm{C}$ than warm-season species $(P=0.0002$; Table 1$)$.

Significant variability in virulence, based on AUDPC values, was observed among isolates within some species of Pythium (Table 1). Of the three isolates of $P$. spinosum, isolate N18-13 was less virulent than isolates N18-2 and N18-4, which were equally virulent. For

Table 3. Categorical analysis of variance parameters for proportions of diseased cucurbits from which Pythium species were recovered in nine fields in South Carolina on four sampling dates in 2017 and 2018

\begin{tabular}{|c|c|c|c|c|c|c|c|c|c|c|}
\hline \multirow[b]{2}{*}{ Source } & \multicolumn{2}{|c|}{$\begin{array}{c}P . \\
\text { aphanidermatum }\end{array}$} & \multicolumn{2}{|c|}{$P$. irregulare } & \multicolumn{2}{|c|}{ P. myriotylum } & \multicolumn{2}{|c|}{ P. spinosum } & \multicolumn{2}{|c|}{ Total recovery } \\
\hline & $x^{2}$ & $P$ value & $x^{2}$ & $P$ value & $x^{2}$ & $P$ value & $x^{2}$ & $P$ value & $x^{2}$ & $P$ value \\
\hline Intercept & 26.12 & $<0.0001$ & 64.73 & $<0.0001$ & 6.05 & 0.01 & 33.02 & $<0.0001$ & 0.57 & 0.45 \\
\hline Year $^{\mathrm{v}}$ & 0.23 & 0.63 & 0.54 & 0.46 & 2.16 & 0.14 & 0 & 0.99 & 16.56 & $<0.0001$ \\
\hline Month $^{w}$ & 35.20 & $<0.0001$ & 11.69 & 0.01 & 67.20 & $<0.0001$ & 93.53 & $<0.0001$ & 36.74 & $<0.0001$ \\
\hline Year $\times$ month & 6.96 & 0.07 & 1.35 & 0.72 & 3.76 & 0.29 & $\ldots$ & $\ldots$ & 15.88 & 0.0012 \\
\hline Field type ${ }^{\mathrm{x}}$ & 0.06 & 0.80 & 1.68 & 0.20 & 0.05 & 0.82 & 2.03 & 0.15 & 0.03 & 0.87 \\
\hline Year $\times$ field type & 2.94 & 0.09 & $\ldots$ & $\ldots$ & 3.49 & 0.06 & $\ldots$ & $\ldots$ & 3.87 & 0.049 \\
\hline Month $\times$ field type & 0.39 & 0.94 & 10.55 & 0.01 & 0.08 & 0.99 & 9.79 & 0.02 & 4.60 & 0.20 \\
\hline Year $\times$ month $\times$ field type & 7.85 & 0.049 & $\ldots$ & $\ldots$ & 8.96 & 0.03 & $\ldots$ & $\ldots$ & 4.60 & 0.20 \\
\hline Host $^{\mathrm{y}}$ & 8.21 & 0.04 & 1.24 & 0.74 & 3.56 & 0.31 & 1.71 & 0.64 & 4.26 & 0.24 \\
\hline Month $\times$ host & $\ldots^{\mathrm{z}}$ & $\ldots$ & $\ldots$ & $\ldots$ & $\ldots$ & $\ldots$ & $\ldots$ & $\ldots$ & 9.27 & 0.41 \\
\hline Field type $\times$ host & $\ldots$ & $\ldots$ & 3.61 & 0.31 & $\ldots$ & $\ldots$ & $\ldots$ & $\ldots$ & 2.46 & 0.48 \\
\hline Month $\times$ field type $\times$ host & $\ldots$ & $\cdots$ & $\ldots$ & $\ldots$ & $\ldots$ & $\ldots$ & $\ldots$ & $\ldots$ & 10.08 & 0.26 \\
\hline Likelihood ratio & 19.27 & 0.99 & 12.01 & 1.00 & 20.27 & 0.98 & 25.68 & 0.98 & 7.11 & 1.00 \\
\hline
\end{tabular}

v 2017 or 2018.

w May, July, September, or November.

$x$ Organic or conventionally managed field.

y Bottle gourd, cucumber, Hubbard squash, or watermelon.

$\mathrm{z}$ Indicates source of variation eliminated in stepwise model reduction to improve sensitivity of analysis. 
three isolates of $P$. myriotylum, isolate M18-a8 was less virulent than isolate M18-1, but isolates M18a8 and $\mathrm{J} 18-32$ were similar in virulence. Four isolates of $P$. aphanidermatum were evaluated, and isolate M17-42 was less virulent than isolate M18-5, but each of these isolates was similar in virulence to isolates N18-5 and J17-23. There were no significant differences in virulence observed between the two isolates of $P$. ultimum nor between the two isolates of $P$. irregulare.

Fungicide sensitivity. Sixty-four representative isolates were evaluated for sensitivity to mefenoxam, 63 isolates were evaluated for sensitivity to propamocarb, and 68 isolates were evaluated for sensitivity to oxathiapiprolin-including four isolates in Pythium spp. clade I that were obtained from other researchers.

Mycelium growth of 64 isolates of Pythium spp. and Phy. helicoides was affected significantly by the fungicide mefenoxam based on $\mathrm{EC}_{50}$ values $(P<0.0011)$. $\mathrm{EC}_{50}$ values for all isolates ranged from $<0.006$ to $0.519 \mathrm{mg}$ of a.i./liter, with significant variation observed among species (Table 6). Some isolates of Phy. helicoides, Pythium coloratum/dissotocum, $P$. irregulare, and $P$. aphanidermatum were relatively less sensitive, with $\mathrm{EC}_{50}$ values of $>0.4 \mathrm{mg}$ of a.i./liter. $P$ Py. helicoides and $P$. coloratum/dissotocum were significantly less sensitive than $P$. myriotylum, $P$. acanthicum, $P$. spinosum, and $P$. ultimum. $\mathrm{EC}_{50}$ values for five isolates of $P$. ultimum and $P$. splendens were $<0.1 \mathrm{mg}$ of a.i./liter. Among the 10 species, $\mathrm{EC}_{50}$ values varied the most among isolates of Phy. helicoides $(\mathrm{SE}=0.21)$, because the two isolates had $\mathrm{EC}_{50}$ values of 0.09 and $0.52 \mathrm{mg}$ of a.i./liter.

Mycelium growth of 63 isolates of Pythium spp. and Phy. helicoides was affected significantly by the fungicide propamocarb based on $\mathrm{EC}_{50}$ values $(P<0.0001)$. There was considerable variation observed among species because mean $\mathrm{EC}_{50}$ values ranged from 0.03 to $6.7 \mathrm{mg}$ of a.i./liter (Table 7). Some isolates of P. ultimum, P. splendens, and $P$. irregulare were relatively less sensitive, with $\mathrm{EC}_{50}$ values of $\geq 6.0 \mathrm{mg}$ of a.i./liter. $P$. ultimum and $P$. irregulare were significantly less sensitive than all other species. $P$. splendens was not included in the analysis because only one isolate was assayed. $P$. sylvaticum, $P$. acanthicum, $P$. myriotylum, $P$. coloratum/dissotocum, and Phy. helicoides were among the most sensitive species, because all isolates had $\mathrm{EC}_{50}$ values of $\leq 2.0 \mathrm{mg}$ of a.i./liter, and all five

Table 4. Proportion of recovery of four Pythium spp. recovered from diseased cucurbits planted in nine fields in South Carolina on four sampling dates in 2017 and 2018

\begin{tabular}{lcccccccccc}
\hline & \multicolumn{7}{c}{ Proportion of recovery } \\
\cline { 2 - 10 } Month & $\boldsymbol{P . \text { aphanidermatum }}$ & SE $^{\mathbf{y}}$ & $\boldsymbol{P .}$ myriotylum & SE & $\boldsymbol{P .}$ irregulare & SE & $\boldsymbol{P .}$ spinosum & SE & Total recovery & SE \\
\hline May & $0.36^{z}$ & 0.06 & 0.51 & 0.06 & 0.19 & 0.05 & 0.21 & 0.05 & 0.47 & 0.05 \\
July & 0.45 & 0.05 & 0.51 & 0.04 & 0.09 & 0.03 & 0.09 & 0.03 & 0.72 & 0.04 \\
September & 0.23 & 0.06 & 0.53 & 0.07 & 0.19 & 0.05 & 0.27 & 0.06 & 0.57 & 0.05 \\
November & 0.08 & 0.02 & 0.08 & 0.08 & 0.31 & 0.03 & 0.65 & 0.03 & 0.48 & 0.05 \\
\hline
\end{tabular}

y Standard error.

${ }^{\mathrm{z}}$ Proportions presented are back-transformed logit values.

Table 5. Categorical analysis of variance parameters for proportions of diseased cucurbits from which Pythium species were recovered in nine fields in South Carolina in March 2019

\begin{tabular}{|c|c|c|c|c|c|c|c|c|c|c|}
\hline \multirow[b]{2}{*}{ Source } & \multicolumn{2}{|c|}{ Total recovery } & \multicolumn{2}{|c|}{ P. aphanidermatum } & \multicolumn{2}{|c|}{ P. irregulare } & \multicolumn{2}{|c|}{ P. myriotylum } & \multicolumn{2}{|c|}{ P. spinosum } \\
\hline & $x^{2}$ & $P$ value & $x^{2}$ & $P$ value & $\chi^{2}$ & $P$ value & $\chi^{2}$ & $P$ value & $x^{2}$ & $P$ value \\
\hline Intercept & 0.31 & 0.5762 & 7.30 & 0.0069 & 6.89 & 0.0087 & 7.30 & 0.0069 & 1.97 & 0.1601 \\
\hline Field type ${ }^{y}$ & 4.11 & 0.0427 & 0.20 & 0.65 & 0.30 & 0.58 & 0.20 & 0.65 & 0.48 & 0.49 \\
\hline $\mathrm{Host}^{\mathrm{z}}$ & 8.43 & 0.0379 & 1.83 & 0.40 & 1.57 & 0.46 & 1.83 & 0.40 & 2.81 & 0.24 \\
\hline Likelihood ratio & 0.85 & 0.65 & 0.05 & 0.97 & 0.04 & 0.98 & 0.05 & 0.97 & 0.62 & 0.73 \\
\hline
\end{tabular}

y Organic or conventionally managed field.

${ }^{\mathrm{z}}$ Bottle gourd, cucumber, Hubbard squash, or watermelon.

Table 6. Effective concentration of mefenoxam that reduced relative colony diameter by $50 \%$ ( $\mathrm{EC}_{50}$ values) for isolates of species of Pythium and one species of Phytopythium recovered from diseased cucurbits in South Carolina in 2017, 2018, and 2019

\begin{tabular}{|c|c|c|c|c|c|c|c|c|c|}
\hline \multirow[b]{2}{*}{ Species } & \multirow[b]{2}{*}{ No. of isolates } & \multirow{2}{*}{$\begin{array}{l}\text { Mean } E_{50} \text { value } \\
\left(^{(m g ~ o f ~ a . i . / l i t e r) ~}\right.\end{array}$} & \multirow[b]{2}{*}{$\mathbf{S E}^{\mathrm{x}}$} & \multicolumn{6}{|c|}{ Distribution of isolates based on $\mathbf{E C}_{50}$ values (mg of a.i./liter) } \\
\hline & & & & $<0.1$ & $0.1-0.2$ & $0.21-0.3$ & $0.31-0.4$ & $0.41-0.5$ & $0.51-0.6$ \\
\hline P. splendens ${ }^{\mathrm{y}}$ & 1 & 0.006 & $\ldots$ & 1 & $\ldots$ & $\ldots$ & $\ldots$ & $\ldots$ & $\ldots$ \\
\hline P. ultimum & 4 & $0.012 \mathrm{~d}^{\mathrm{z}}$ & 0.01 & 4 & $\ldots$ & $\ldots$ & $\ldots$ & $\ldots$ & $\ldots$ \\
\hline P. spinosum & 11 & $0.092 \mathrm{c}$ & 0.01 & 2 & 8 & 1 & $\ldots$ & $\ldots$ & $\ldots$ \\
\hline P. acanthicum & 2 & $0.108 \mathrm{bcd}$ & 0.02 & 1 & 1 & $\ldots$ & $\ldots$ & $\ldots$ & $\ldots$ \\
\hline P. aphanidermatum & 14 & $0.112 a b$ & 0.04 & 2 & 7 & 1 & 1 & 2 & 1 \\
\hline P. myriotylum & 17 & $0.126 \mathrm{c}$ & 0.01 & 3 & 14 & $\ldots$ & $\ldots$ & $\ldots$ & $\ldots$ \\
\hline P. sylvaticum ${ }^{\mathrm{y}}$ & 1 & 0.155 & $\ldots$ & $\ldots$ & 1 & $\ldots$ & $\ldots$ & $\ldots$ & $\ldots$ \\
\hline P. irregulare & 8 & $0.205 \mathrm{ab}$ & 0.05 & $\ldots$ & 4 & 2 & 1 & $\ldots$ & 1 \\
\hline P. coloratum/dissotocum & 4 & $0.282 \mathrm{a}$ & 0.06 & $\ldots$ & 1 & 1 & 1 & 1 & $\ldots$ \\
\hline Phytopythium helicoides & 2 & $0.519 \mathrm{a}$ & 0.21 & 1 & $\ldots$ & $\ldots$ & $\ldots$ & $\ldots$ & 1 \\
\hline
\end{tabular}

${ }^{\mathrm{w}}$ Data from two trials were combined. $\mathrm{EC}_{50}$ values were calculated for each isolate by regressing relative colony radii in corn meal agar against the base-10 logarithm of the concentrations of mefenoxam. a.i. = active ingredient.

x Standard error.

y Not included in statistical analysis because only one isolate was assayed.

${ }^{\mathrm{z}}$ Mean $\mathrm{EC}_{50}$ values followed by the same letter are not significantly different according to Fisher's protected least significant difference $(P<0.05)$. 
species had mean $\mathrm{EC}_{50}$ values of $<1.0 \mathrm{mg}$ of a.i./liter. P. irregulare isolates were the most variable $(\mathrm{SE}=1.51)$ with $\mathrm{EC}_{50}$ values ranging from 0.35 to $13.24 \mathrm{mg}$ of a.i./liter.

Fifty-nine isolates in six taxonomic clades of the genus Pythium were not sensitive to the fungicide oxathiapiprolin, with relative colony diameters similar to those of the controls even at $100 \mathrm{mg}$ of a.i./ liter, but nine isolates in Pythium clade I were sensitive to this fungicide with $\mathrm{EC}_{50}$ values of $\leq 1.05 \mathrm{mg}$ of a.i./liter (Table 8). Pythium clade I includes the species $P$. ultimum var. ultimum, $P$. ultimum var. sporangiiferum, $P$. heterothallicum, and $P$. splendens. Among the species sensitive to oxathiapiprolin, isolates of $P$. ultimum var. ultimum were most sensitive, and isolates of $P$. heterothallicum were least sensitive (Table 8).

\section{Discussion}

Eight species of Pythium and Phy. helicoides were recovered from four cucurbits during a 3-year survey. The most commonly isolated species of Pythium were $P$. spinosum, $P$. irregulare, $P$. myriotylum, and $P$. aphanidermatum. Because of the low recovery rates of the other five species, these four species should be considered the most important species on cucurbits in coastal South Carolina and could be important pathogens on cucurbits in the southeastern coastal plain. These four Pythium species were recovered from all four cucurbit hosts, demonstrating their ability to cause disease on four genera cultivated in the family Cucurbitaceae. More isolates were recovered from watermelon than from Hubbard squash, cucumber, and bottle gourd. Bottle gourd and interspecific hybrid squash (Cucurbita maxima $\times$ C. moschata) are used as cucurbit rootstocks to manage several other soilborne pathogens (Keinath and Hassell 2014; King et al. 2008). They have been shown to be effective rootstocks for controlling Pythium disease, possibly explaining the reduced disease incidence and isolate recovery on bottle gourd and Hubbard squash in this study (Al-Mawaali et al. 2012; Toporek and Keinath 2019).

$P$. myriotylum, $P$. aphanidermatum, and $P$. irregulare were the most abundant species collected in a survey of greenhouse floriculture crops in North Carolina (Lookabaugh et al. 2015). Likewise, $P$. irregulare and $P$. aphanidermatum were two of the main species found in a greenhouse floriculture survey in Michigan (Del Castillo Múnera and Hausbeck 2016). These four species also were recovered from bell pepper in Florida (Chellemi et al. 2000). P. aphanidermatum has a wide host range (Martin and Loper 1999). The recovery of these species may be explained by their ubiquitous distribution rather than specific attributes of the cucurbit hosts.

$P$. spinosum and $P$. irregulare were recovered primarily in November and March, months with cool weather, whereas recovery of $P$. myriotylum and $P$. aphanidermatum occurred primarily in warm months, May and July. $P$. spinosum and $P$. irregulare were never recovered in July, and, conversely, $P$. myriotylum and
$P$. aphanidermatum were never recovered in November or March. The fluctuation between $P$. spinosum and $P$. aphanidermatum recovery is similar to results recently described in Israel (Philosoph et al. 2019). Both species were isolated from cucumber in transitional months, but $P$. aphanidermatum and $P$. spinosum were found strictly in the warmest and coolest months, respectively. Seasonal effects also have been observed with recovery of propagules of Pythium spp. Ali-Shtayeh (1986) found higher numbers of colony forming units of $P$. aphanidermatum in cultivated fields in months with warmer weather. In a study on Pythium blight, examining sieved thatch from golf courses in Ohio, $P$. aphanidermatum propagule counts were highest in the winter and then declined in the spring (Hall et al. 1980). This was attributed to the reduction in survival of propagules as P. aphanidermatum became biologically active. A similar fluctuation in propagule numbers was observed in sugar beet soils in Arizona (Stanghellini et al. 1982). As a component of seasonality, temperature alone was shown to significantly influence species recovery. In New York, $P$. ultimum and $P$. irregulare were recovered frequently when the soil temperature was $21^{\circ} \mathrm{C}$, but $P$. oligandrum was predominantly recovered from samples incubated at $37^{\circ} \mathrm{C}$ (Pieczarka and Abawi 1978). Growth rate of the mycelium of P. aphanidermatum, $P$. ultimum, and $P$. deliense in culture at different temperatures also reflects the differences between species' environmental preferences (Teymoori et al. 2012).

The dramatic increase in numbers of isolates of Pythium spp. collected in November and March was a function of the criteria established to designate which plants to collect. Aboveground symptoms of stunting or wilting caused by cold temperatures are indistinguishable from those caused by Pythium spp., so cold injury may have led to more plants being collected. Optimal growing temperatures for cucurbits should not be lower than $18.3^{\circ} \mathrm{C}$ for cucumber and squash and $23.8^{\circ} \mathrm{C}$ for watermelon (Maynard and Hochmuth 2007). However, stunted and wilted plants collected in March and November displayed symptoms of discolored roots. Percentage recovery of Pythium from diseased plants was 87.4, 79, and $78 \%$ for November 2017, November 2018, and March 2019, respectively. Additionally, in the virulence assay, $P$. spinosum and $P$. irregulare isolates were among the most aggressive at $25^{\circ} \mathrm{C}$. Both $P$. irregulare and $P$. spinosum, the species recovered most abundantly in cold months, have been reported previously as pathogens of different cucurbit species (Farr and Rossman 2020). P. spinosum also has been reported to cause dieback of mature watermelon in Florida (Hendricks and Roberts 2015).

The temperature for the virulence experiment, $25^{\circ} \mathrm{C}$, represents an average temperature in spring for transplanting watermelon seedlings, based on South Carolina weather data (Keinath et al. 2019). Virulence, like recovery, can be temperature dependent within species and even within isolates of a species (Matthiesen et al. 2016).

Table 7. Effective concentration of propamocarb that reduced relative colony diameter by $50 \%$ ( $\mathrm{EC}_{50}$ values) for 63 isolates of nine species of Pythium and one species of Phytopythium recovered from diseased cucurbits in South Carolina in 2017, 2018, and 2019

\begin{tabular}{|c|c|c|c|c|c|c|c|c|c|}
\hline \multirow[b]{2}{*}{ Species } & \multirow[b]{2}{*}{ No. of isolates } & \multirow{2}{*}{$\begin{array}{c}\text { Mean EC } \mathrm{EC}_{50} \\
\text { (mg of a.i.//liter) }^{\mathrm{w}}\end{array}$} & \multirow[b]{2}{*}{$\mathbf{S E}^{\mathbf{x}}$} & \multicolumn{6}{|c|}{ Distribution of isolates based on $\mathrm{EC}_{50}$ values (mg of a.i./liter) } \\
\hline & & & & $<0.1$ & $0.1-2.0$ & 2.1-4.0 & 4.1-6.0 & 6.1-8.0 & $>8.0$ \\
\hline P. sylvaticum ${ }^{\mathrm{y}}$ & 1 & 0.03 & $\ldots$ & 1 & $\ldots$ & $\ldots$ & $\ldots$ & $\ldots$ & $\ldots$ \\
\hline P. acanthicum & 2 & $0.49 \mathrm{bc}^{\mathrm{z}}$ & 0.03 & $\ldots$ & 2 & $\ldots$ & $\ldots$ & $\ldots$ & $\ldots$ \\
\hline P. myriotylum & 17 & $0.61 \mathrm{c}$ & 0.11 & 3 & 14 & $\ldots$ & $\ldots$ & $\ldots$ & $\ldots$ \\
\hline P. coloratum/dissotocum & 4 & $0.74 \mathrm{bc}$ & 0.41 & 1 & 3 & $\ldots$ & $\ldots$ & $\ldots$ & $\ldots$ \\
\hline Phytopythium helicoides ${ }^{\mathrm{y}}$ & 1 & 0.75 & $\ldots$ & $\ldots$ & 1 & $\ldots$ & $\ldots$ & $\ldots$ & $\ldots$ \\
\hline P. spinosum & 11 & $2.06 \mathrm{~b}$ & 0.41 & $\ldots$ & 5 & 5 & 1 & $\ldots$ & $\ldots$ \\
\hline P. aphanidermatum & 14 & $2.13 \mathrm{~b}$ & 0.18 & $\ldots$ & 9 & 5 & $\ldots$ & $\ldots$ & $\ldots$ \\
\hline P. irregulare & 8 & $4.63 \mathrm{a}$ & 1.51 & $\ldots$ & 3 & $\ldots$ & 3 & 1 & 1 \\
\hline P. splendens $\mathrm{y}^{\mathrm{y}}$ & 1 & 6.05 & $\ldots$ & $\ldots$ & $\ldots$ & $\ldots$ & $\ldots$ & 1 & $\ldots$ \\
\hline P. ultimum & 4 & $6.70 \mathrm{a}$ & 0.91 & $\ldots$ & $\ldots$ & $\ldots$ & 1 & 2 & 1 \\
\hline
\end{tabular}

${ }^{\mathrm{w}}$ Data from two trials were combined. $\mathrm{EC}_{50}$ values were calculated for each isolate by regressing relative colony radii in $20 \%$ clarified V8 agar against the base-10 logarithm of the concentrations of propamocarb. a.i. = active ingredient.

x Standard error.

y Not included in statistical analysis because only one isolate was assayed.

${ }^{z}$ Means followed by the same letter are not significantly different according to Fisher's protected least significant difference $(P \leq 0.05)$. 
Although $P$. aphanidermatum and $P$. myriotylum were the least virulent species, this result may be due to the assay temperature. $P$. myriotylum was the most virulent species on tomato at $35^{\circ} \mathrm{C}$, whereas $P$. aphanidermatum was most virulent between 27 and $35^{\circ} \mathrm{C}$ (Littrell and McCarter 1970). Bell pepper mortality was highest at $34^{\circ} \mathrm{C}$ when inoculated with $P$. aphanidermatum and $P$. myriotylum (Chellemi et al. 2000).

Variability in virulence among isolates of Pythium spp. has been observed previously (Del Castillo Múnera and Hausbeck 2016; Rojas et al. 2017a). The lack of disease caused by isolates of Phy. helicoides and $P$. coloratum/dissotocum may be due to loss of virulence during storage or weak virulence. Both of these species were infrequently isolated in the field throughout the survey. However, it is interesting that, although $P$. ultimum was the most virulent species, it was not frequently recovered. The abundance and virulence of $P$. spinosum and $P$. irregulare demonstrate the significant threat that these species pose to early season cucurbit transplants.

How early in the growing season a seedling is transplanted influences its exposure to particular species of Pythium. In South Carolina, typical transplanting dates range from mid-March to mid-June (Kemble et al. 2020). Thus, growers planting early will most likely encounter $P$. spinosum and $P$. irregulare with a transition into disease caused by $P$. myriotylum and $P$. aphanidermatum later in the season. Young plants growing at cool temperatures tend to mature slowly, keeping them longer in a state more susceptible to infection by Pythium spp. (Martin and Loper 1999). With early planting, a cucurbit crop potentially would be exposed to both cool-season and warm-season species of Pythium throughout its lifecycle compared with one planted later when soil is warmer. Consequently, early planting may contribute to higher overall disease.

Although seasonality appears be a large factor influencing Pythium species isolation, species diversity has been shown to be a function of several other environmental and edaphic factors, such as latitude, rainfall, soil clay content, $\mathrm{pH}$, field capacity, cation exchange capacity, calcium carbonate equivalent, and various minerals (e.g., calcium, magnesium, and zinc) (Broders et al. 2009; Rojas et al. 2017b; Zitnick-Anderson et al. 2017). The dominant species recovered can differ between sampling locations within a field (Bakker et al. 2017). The diversity of Pythium spp. recovered could also be associated with ability to grow on the medium used for isolation; indeed $P$. aphanidermatum, $P$. ultimum, and $P$. irregulare, three of the five major species recovered in this survey, are species with fast growth rates on CMA (Jeffers and Martin 1986).

Total recovery rate did not differ significantly between conventionally or organically managed fields in 2017 and 2018 in any month; however, in 2017 and 2018, recovery of $P$. irregulare was greater in conventional fields than in organic fields, but, conversely, recovery of $P$. spinosum was greater in organic fields than in conventional fields. In March 2019, Pythium spp. were recovered more frequently in organic fields than in conventional fields. Because the predominant taxon recovered in March 2019 was $P$. spinosum, its frequency could have resulted in greater total recovery rates in organic fields. This study did not characterize or determine the individual management strategies used in all conventional or organic fields sampled, so it is not possible to identify reasons for the abundance of $P$. irregulare or $P$. spinosum in fields with different cultural management practices.

All isolates of Pythium spp. and Phy. helicoides tested were sensitive to mefenoxam and propamocarb in vitro, demonstrating the potential utility of these two fungicides for use in cucurbit production in South Carolina. Sensitivity to mefenoxam and the degree of variation among isolates were similar to other studies reporting $\mathrm{EC}_{50}$ values for isolates in forest nurseries in Washington and alfalfa fields in Minnesota (Berg et al. 2017; Weiland et al. 2014). None of our observed $\mathrm{EC}_{50}$ values reached those of resistant isolates in other studies for mefenoxam or propamocarb (Del Castillo Múnera and Hausbeck 2016; Lookabaugh et al. 2015; Moorman and Kim 2004; Weiland et al. 2014). It should be noted that the use of CMA and 5\% V8A as a basal medium for fungicide sensitivity has an effect on the perceived $\mathrm{EC}_{50}$ value (Shew 1984). In addition, in vitro sensitivity of an isolate to propamocarb is not always a reliable predictor for sensitivity in planta (Moorman and Kim 2004).

Oxathiapiprolin is not labeled to manage Pythium spp.; however, an isolate of $P$. ultimum var. ultimum in Pythium clade I was reported to be moderately sensitive to oxathiapiprolin, albeit at higher concentrations compared with other oomycetes tested (Miao et al. 2016). Pythium clade I species lack commonality in morphological characteristics or obvious origin (LéVesque and De Cock 2004). To validate that clade I isolates were sensitive, three isolates of $P$. heterothallicum and one isolate of P. ultimum var. sporangiiferum

Table 8. Effective concentration of oxathiapiprolin that reduced relative colony diameter by $50 \%$ (EC 50 values) for isolates of species of Pythium and one species of Phytopythium

\begin{tabular}{|c|c|c|c|c|}
\hline Clade & Species (no. of isolates) & Sensitivity & Isolate & $\mathrm{EC}_{50}$ value (mg of a.i./liter) ${ }^{\mathrm{w}}$ \\
\hline \multirow[t]{9}{*}{ I } & $P$. aff. ultimum var. ultimum $^{\mathrm{x}}$ & Sensitive & M17-56 & 0.15 \\
\hline & $P$. aff. ultimum var. ultimum & Sensitive & M17-47 & 0.16 \\
\hline & $P$. aff. ultimum var. ultimum & Sensitive & M18-a17 & 0.18 \\
\hline & $P$. aff. ultimum var. ultimum & Sensitive & $\mathrm{J} 17-3$ & 0.29 \\
\hline & P. splendens & Sensitive & M18-a10 & 0.56 \\
\hline & $P$. aff. ultimum var. sporangiiferum & Sensitive & C12-99y & 0.56 \\
\hline & P. heterothallicum & Sensitive & $\mathrm{C} 12-171^{\mathrm{y}}$ & 0.45 \\
\hline & P. heterothallicum & Sensitive & $2 \_9^{\mathrm{z}}$ & 0.62 \\
\hline & P. heterothallicum & Sensitive & $2 \_11^{\mathrm{z}}$ & 1.05 \\
\hline A & P. aphanidermatum (14) & Unaffected & Various & $>100$ \\
\hline $\mathrm{B} 1$ & P. myriotylum (17) & Unaffected & Various & $>100$ \\
\hline B2 & P. coloratum/dissotocum (4) & Unaffected & Various & $>100$ \\
\hline $\mathrm{D}$ & P. acanthicum (2) & Unaffected & Various & $>100$ \\
\hline \multirow[t]{3}{*}{$\mathrm{F}$} & P. spinosum (11) & Unaffected & Various & $>100$ \\
\hline & P. irregulare (8) & Unaffected & Various & $>100$ \\
\hline & P. sylvaticum (1) & Unaffected & Various & $>100$ \\
\hline $\mathrm{K}$ & Phytopythium helicoides (2) & Unaffected & Various & $\ldots$ \\
\hline
\end{tabular}

${ }^{\mathrm{w}}$ Data from two trials were combined. $\mathrm{EC}_{50}$ values were calculated for each isolate by regressing relative colony radii in corn meal agar against the base-10 logarithm of the concentrations of oxathiapiprolin. a.i. = active ingredient.

x Species that cannot be $100 \%$ determined using COX1 sequencing are labeled as aff., which indicates that this is the species voucher that was identified, but that does not necessarily indicate a match.

y Isolates provided by Dr. Jamie Blair, Franklin \& Marshall College. Recovered from soybean. Identified in Coffua et al. (2016) with COX1 sequencing.

z Isolates provided by Dr. Barbara Shew, North Carolina State University. Recovered from wheat. Identified with ITS sequencing (unpublished). Both isolates have $99.8 \%$ similarity to a verified isolate of $P$. heterothallicum (HQ643562). 
were obtained from other researchers. These isolates and the five isolates from the survey were sensitive to oxathiapiprolin at concentrations $\leq 1 \mathrm{mg}$ of a.i./liter. The moderately sensitive species of Pythium were far more tolerant to oxathiapiprolin than other oomycete pathogens (Bittner and Mila 2016). The target of oxathiapiprolin is said to be the oxysterol binding protein (OSBP) (Pasteris et al. 2015). Isolates from 14 species of Pythium and Phytophthora formed separate phylogenetic clusters based on the OSBP sequences; however, the OSBPs of $P$. ultimum and $P$. aphanidermatum were similar (Miao et al. 2016). This may suggest some other mechanism of sensitivity to oxathiapiprolin in Pythium clade I isolates. All other isolates from eight Pythium species, representing five clades, and Phy. helicoides collected in this survey were insensitive, whereas an isolate from every described species from clade I was sensitive.

This study identified a seasonal change in recovery of Pythium species and Phy. helicoides from diseased cucurbit seedlings, variability in virulence of Pythium species and isolates and Phy. helicoides on a susceptible watermelon cultivar, and sensitivity of isolates of Pythium spp. and Phy. helicoides recovered from cucurbits to mefenoxam and propamocarb in vitro. Previously, 24 species of Pythium had been reported on various cultivated cucurbits, with more than half of the reports coming from Cucumis sativus. The geographical area covered in this survey, however, could limit broad conclusions on the overall diversity of Pythium species associated with cucurbits. This is the first published study of Pythium and Phytopythium species on cucurbits in South Carolina or the United States, and it is one of a few studies to consider the effect of sampling date and multiple hosts on recovery of different species. Knowing the identity and infection window of these Pythium species will help facilitate development of cultural management strategies and breeding efforts to manage Pythium species on cucurbits.

\section{Acknowledgments}

The authors thank Ginny Dubose, Sierra Zardus, and Casey Conrad for their assistance with field preparation and maintenance; Dr. Barbara Shew, North Carolina State University, Raleigh, NC, and Dr. Jamie Blair, Franklin \& Marshall College, Lancaster, PA, for supplying Pythium clade I isolates for oxathiapiprolin screening; Dr. Steven Jeffers, Clemson University, for reviewing this manuscript; and the cooperating farmers who provided the land for our sentinel plots.

\section{Literature Cited}

Al-Mawaali, Q. S., Al-Sadi, A. M., Khan, A. J., Al-Hasani, H. D., and Deadman, M. L. 2012. Response of cucurbit rootstocks to Pythium aphanidermatum. Crop Prot. 42:64-68.

Al-Sadi, A. M., Al-Ghaithi, A. G., Al-Balsuhi, Z. M., and Al-Jabri, A. H. 2012. Analysis of diversity in Pythium aphanidermatum populations from a single greenhouse reveals phenotypic and genotypic changes over 2006 to 2011. Plant Dis. 96:852-858.

Al-Sadi, A. M., Drenth, A., Deadman, M. L., De Cock, A. W. A. M., and Aitken, E. A. B. 2007. Molecular characterization and pathogenicity of Pythium species associated with damping-off in greenhouse cucumber (Cucumis sativus) in Oman. Plant Pathol. 56:140-149.

Ali-Shtayeh, M. S. 1986. Seasonal variation in population levels of Pythium species in irrigated and non-irrigated fields in the West Bank of Jordan and the Gaza Strip. Trans. Brit. Mycol. Soc. 87:503-509.

Bakker, M. G., Moorman, T. B., Kaspar, T. C., and Manter, D. K. 2017. Isolation of cultivation-resistant oomycetes, first detected as amplicon sequences, from roots of herbicide-terminated winter rye. Phytobiomes 1:24-35.

Berg, L. E., Miller, S. S., Dornbusch, M. R., and Samac, D. A. 2017. Seed rot and damping-off of alfalfa in Minnesota caused by Pythium and Fusarium species. Plant Dis. 101:1860-1867.

Bittner, R. J., and Mila, A. L. 2016. Effects of oxathiapiprolin on Phytophthora nicotianae, the causal agent of black shank of tobacco. Crop Prot. 81:57-64.

Broders, K. D., Wallhead, M. W., Austin, G. D., Lipps, P. E., Paul, P. A., and Dorrance, A. E. 2009. Association of soil chemical and physical properties with Pythium species diversity, community composition, and disease incidence. Phytopathology 99:957-967.

Chellemi, D. O., Mitchell, D. J., Kannwischer-Mitchell, M. E., Rayside, P. A., and Rosskopf, E. N. 2000. Pythium spp. associated with bell pepper production in Florida. Plant Dis. 84:1271-1274.

Coffua, L. S., Veterano, S. T., Clipman, S. J., Mena-Ali, J. I., and Blair, J. E. 2016. Characterization of Pythium spp. associated with asymptomatic soybean in southeastern Pennsylvania. Plant Dis. 100:1870-1879.

Cohen, Y. 2015. The novel oomycide oxathiapiprolin inhibits all stages in the asexual life cycle of Pseudoperonospora cubensis-causal agent of cucurbit downy mildew. PLoS One 10:e0140015.
Davis, A. R., Perkins-Veazie, P., Sakata, Y., López-Galarza, S., Maroto, J. V., Lee, S. G., Huh, Y. C., Sun, Z., Miguel, A., King, S. R., Cohen, R., and Lee, J. M. 2008. Cucurbit grafting. Crit. Rev. Plant Sci. 27:50-74.

de Cock, A. W. A. M., Lodhi, A. M., Rintoul, T. L., Bala, K., Robideau, G. P., Abad, G. Z., Coffey, M. D., Shahzad, S., and Lévesque, C. A. 2015. Phytopythium: Molecular phylogeny and systematics. Persoonia 34:25-39.

Deadman, M. L. 2017. Pythium and Phytophthora damping-off and root rot. Pages 48-50 in: Compendium of Cucurbit Diseases and Pests, 2 nd Ed., A. P. Keinath, T. A Zitter, and W. M. Wintermantel, eds. American Phytopathological Society, St. Paul.

Del Castillo Múnera, J., and Hausbeck, M. K. 2016. Characterization of Pythium species associated with greenhouse floriculture crops in Michigan. Plant Dis. 100:569-576.

Dissanayake, N., and Hoy, J. W. 1999. Organic material soil amendment effects on root rot and sugarcane growth and characterization of the materials. Plant Dis. 83:1039-1046.

Farr, D. F., and Rossman, A. Y. 2020. Fungal Databases, U.S. National Fungus Collections, ARS, USDA. Retrieved April 3, 2020. https://nt.ars-grin.gov/ fungaldatabases/

Hall, T. J., Larsen, P. O., and Schmitthenner, A. F. 1980. Survival of Pythium aphanidermatum in golf course turfs. Plant Dis. 64:1100-1103.

Hartmann, M., Frey, B., Mayer, J., Mäder, P., and Widmer, F. 2015. Distinct soil microbial diversity under long-term organic and conventional farming. ISME J. 9:1177-1194.

Hendricks, K. E., and Roberts, P. D. 2015. First report of Pythium spinosum as a pathogen of watermelon and in association with a dieback of watermelon in southwest Florida. Plant Health Prog. 16:77-79.

Jeffers, S. N., and Martin, S. B. 1986. Comparison of two media selective for Phytophthora and Pythium species. Plant Dis. 70:1038-1043.

Keinath, A. P. 2015. Baseline sensitivity of Didymella bryoniae to cyprodinil and fludioxonil and field efficacy of these fungicides against isolates resistant to pyraclostrobin and boscalid. Plant Dis. 99:815-822.

Keinath, A. P., Coolong, T. W., Lanier, J. D., and Ji, P. 2019. Managing Fusarium wilt of watermelon with delayed transplanting and cultivar resistance. Plant Dis. 103:44-50.

Keinath, A. P., and Hassell, R. L. 2014. Suppression of Fusarium wilt caused by Fusarium oxysporum f. sp. niveum race 2 on grafted triploid watermelon. Plant Dis. 98:1326-1332.

Kemble, J. M., Meadows, I. M., Jennings, K. M., and Walgenbach, J. F., eds. 2020. Vegetable crop handbook for the southeastern United States. http:// www.vegcrophandbook.com/

King, S. R., Davis, A. R., Liu, W., and Levi, A. 2008. Grafting for disease resistance. HortScience 43:1673-1676.

LéVesque, C. A., and De Cock, A. W. A. M. 2004. Molecular phylogeny and taxonomy of the genus Pythium. Mycol. Res. 108:1363-1383.

Littrell, R. H. and McCarter, S. M. 1970. Effect of soil temperature on virulence of Pythium aphanidermatum and Pythium myriotylum to rye and tomato. Phytopathology 60:704-707.

Lookabaugh, E. C., Ivors, K. L., and Shew, B. B. 2015. Mefenoxam sensitivity, aggressiveness, and identification of Pythium species causing root rot on floriculture crops in North Carolina. Plant Dis. 99:1550-1558.

Lumsden, R. D., Garcia-E, R., Lewis, J. A., and Frias-T, G. A. 1987. Suppression of damping-off caused by Pythium spp. in soil from the indigenous Mexican chinampa agricultural system. Soil Biol. Biochem. 19:501-508.

Martin, F. N., and Loper, J. E. 1999. Soilborne plant diseases caused by Pythium spp.: Ecology, epidemiology, and prospects for biological control. Crit. Rev. Plant Sci. 18:111-181.

Matthiesen, R. L., Ahmad, A. A., and Robertson, A. E. 2016. Temperature affects aggressiveness and fungicide sensitivity of four Pythium spp. that cause soybean and corn damping off in Iowa. Plant Dis. 100:583-591.

Maynard, D. N., and Hochmuth, G. J. 2007. Knott's Handbook for Vegetable Growers. Wiley, Hoboken, NJ.

Miao, J., Dong, X., Lin, D., Wang, Q., Liu, P., Chen, F., Du, Y., and Liu, X. 2016. Activity of the novel fungicide oxathiapiprolin against plant-pathogenic oomycetes. Pest Manag. Sci. 72:1572-1577.

Moorman, G. W., and Kim, S. H. 2004. Species of Pythium from greenhouses in Pennsylvania exhibit resistance to propamocarb and mefenoxam. Plant Dis. 88: 630-632.

Njoroge, S. M. C., Riley, M. B., and Keinath, A. P. 2008. Effect of incorporation of Brassica spp. residues on population densities of soilborne microorganisms and on damping-off and Fusarium wilt of watermelon. Plant Dis. 92:287-294.

Pankhurst, C. E., McDonald, H. J., and Hawke, B. G. 1995. Influence of tillage and crop rotation on the epidemiology of Pythium infections of wheat in a redbrown earth of South Australia. Soil Biol. Biochem. 27:1065-1073.

Pasteris, R. J., Hanagan, M. A., Bisaha, J. J., Finkelstein, B. L., Hoffman, L. E., Gregory, V., Shepherd, C. P., Andreassi, J. L., Sweigard, J. A., Klyaschitsky, B. A., Henry, Y. T., and Berger, R. A. 2015. The discovery of oxathiapiprolin: A new, highly-active oomycete fungicide with a novel site of action. ACS Symp. Ser. 1204:149-161.

Philosoph, A. M., Dombrovsky, A., Elad, Y., Koren, A., and Frenkel, O. 2019. Insight into late wilting disease of cucumber demonstrates the complexity of the phenomenon in fluctuating environments. Plant Dis. 103:2877-2883.

Pieczarka, D. J., and Abawi, G. S. 1978. Populations and biology of Pythium species associated with snap bean roots and soils in New York. Phytopathology 68:409-416. 
Robideau, G., De Cock, A. W. A. M., Coffey, M. D., Voglmayr, H., Brouwer, H., Bala, K., Chitty, D. W., D'esaulniers, N., Eggertson, Q. A., Gachon, C. M. M., Hu, C.-H., Küpper, F. C., Rintoul, T. L., Sarhan, E., Verstappen, E. C. P., Zhang, Y., Bonants, P. J. M., Ristaino, J. B., and Lévesque, C. A. 2011. DNA barcoding of oomycetes with cytochrome $c$ oxidase subunit I and internal transcribed spacer. Mol. Ecol. Resour. 11:1002-1011.

Robinson, R. W., and Decker-Walters, D. S. 1997. Cucurbits. CAB International, New York, NY.

Rojas, J. A., Jacobs, J. L., Napieralski, S., Karaj, B., Bradley, C. A., Chase, T., Esker, P. D., Giesler, L. J., Jardine, D. J., Malvick, D. K., Markell, S. G., Nelson, B. D., Robertson, A. E., Rupe, J. C., Smith, D. L., Sweets, L. E., Tenuta, A. U., Wise, K. A., and Chilvers, M. I. 2017a. Oomycete species associated with soybean seedlings in North America-Part I: Identification and pathogenicity characterization. Phytopathology 107:280-292.

Rojas, J. A., Jacobs, J. L., Napieralski, S., Karaj, B., Bradley, C. A., Chase, T., Esker, P. D., Giesler, L. J., Jardine, D. J., Malvick, D. K., Markell, S. G., Nelson, B. D., Robertson, A. E., Rupe, J. C., Smith, D. L., Sweets, L. E., Tenuta, A. U., Wise, K. A., and Chilvers, M. I. 2017b. Oomycete species associated with soybean seedlings in North America-Part II: Diversity and ecology in relation to environmental and edaphic factors. Phytopathology 107:293-304.

Santner, T. J., and Duffy, D. E. 1989. The Statistical Analysis of Discrete Data. Springer, New York, NY. doi.org/10.1007/978-1-4612-1017-7

Schlatter, D. C., Burke, I., and Paulitz, T. C. 2018. Succession of fungal and oomycete communities in glyphosate-killed wheat roots. Phytopathology 108:582-594.

Schroeder, K. L., Martin, F. N., De Cock, A. W. A. M., Okubara, P. A., and Paulitz, T. C. 2013. Molecular detection and quantification of Pythium species: Evolving taxonomy, new tools, and challenges. Plant Dis. 97:4-20.

Shaner, G., and Finney, R. E. 1977. The effect of nitrogen fertilization on the expression of slow-mildewing resistance in Knox wheat. Phytopathology 67: 1051-1056.
Shew, H. D. 1984. In vitro growth response of Phytophthora parasitica var. nicotianae isolates to metalaxyl. Phytopathology 68:764-766.

Stanghellini, M. E., Von-Bretzel, P., Kronland, W. C., and Jenkins, A. D. 1982 Inoculum densities of Pythium aphanidermatum in soils of irrigated sugarbeet fields in Arizona. Phytopathology 72:1481-1485.

Teymoori, S., Shahri, M. H., Rahnama, K, and Afzali, H. 2012. Identification and pathogenicity of Pythium species on sugar beet in Khuzestan Province of Iran. J. Crop Prot. 1:239-247.

Toporek, S., and Keinath, A. P. 2019. Resistance of seedless watermelon grafted onto cucurbit rootstocks to Pythium stem rot, 2018. Plant Dis. Manag. Rep. 13:V159.

United States Department of Agriculture, National Agricultural Statistics Service (USDA-NASS). 2018. Vegetables 2017 Summary. https://www.nass.usda.gov/ Publications/AgCensus/2017/Full_Report/Volume_1,_Chapter_1_US/st99 1_0036_0036.pdf

United States Department of Agriculture, National Agricultural Statistics Service (USDA-NASS). 2019. 2018 Vegetable chemical use, pesticides, watermelons. https://www.nass.usda.gov/Data_and_Statistics/Pre-Defined_Queries/2018_ Vegetables/index.php.

Van der Plaats-Niterink, A. J. 1981. Monograph of the genus Pythium. Stud. Mycol. 21:1-242.

Webster, J., and Weber, R. 2007. Introduction to Fungi. Cambridge University Press, Cambridge, U.K. doi.org/10.1017/CBO9780511809026

Weiland, J. E., Santamaria, L., and Grünwald, N. J. 2014. Sensitivity of Pythium irregulare, $P$. sylvaticum, and $P$. ultimum from forest nurseries to mefenoxam and fosetyl-al, and control of Pythium damping-off. Plant Dis. 98:937-942.

Zitnick-Anderson, K. K., Norland, J. E., del Río Mendoza, L. E., Fortuna, A.-M., and Nelson, B. D. 2017. Probability models based on soil properties for predicting presence-absence of Pythium in soybean roots. Microb. Ecol. 74: 550-560. 